$\left(\begin{array}{l}\text { Jpn. J. Hosp. Pharm. } \\ 26(1) 110-115(2000)\end{array}\right)$

キャピラリー電気泳動法によりフェニトイン中毒を同定した一症例

牧野和隆*, 松永洋子, 中尾泰史, 片岡泰文, 大石了三

九州大学医学部附属病院薬剤部

\title{
A Case Report of Phenytoin Intoxication Identified with Capillary Electrophoresis
}

\author{
KAZUTAKA MAKINO*, YOKO MATSUNAGA, YASUSHI NAKAO, \\ YASUFUMI KATAOKA and RYOZO OISHI \\ Department of Hospital Pharmacy, Faculty of Medicine, Kyushu University $\dagger$
}

\author{
$\left(\begin{array}{l}\text { Received August 30, } 1999 \\ \text { Accepted November 15, } 1999\end{array}\right)$
}

\begin{abstract}
A 2-year and 5-month old male child was admitted to our hospital, deu to signs of antiepileptic drug intoxication. He had been administered zonisamide and valproic acid for the treatment of epilepsy. One day after taking the medicines prepared in an outside pharmacy according to the doctor's prescription, he showed ataxia. The serum valproic acid concentration was within the normal therapeutic range, when measured using the fluorescence polarization immunoassay method (FPIA). We assayed the zonisamide concentration in patient serum using the capillary electrophoresis method. The peak of zonisamide was very low, but another extremely high peak was found. This peak was identified as phenytoin based on the migration time and absorption spectrum. We therefore concluded that the patient fell into phenytoin intoxication by taking a large amount of phenytoin that had been incorrectly prepared. The capillary electrophoresis method appears to be useful for therapeutic drug monitoring, especially in drug intoxication, because of its specificity of separation, simultaneous determination, speed of analysis, and small injection volume.
\end{abstract}

Key words — phenytoin, antiepileptic drug, intoxication, capillary electrophoresis

\section{緒言}

当薬殽部では特定薬骫治療管理料の算定が可能 となった1981年より TDM 業務を開始し, 現在測 定対象薬物は20種類を超え, 年間総測定件数は約 6,000件にのぼる．当初から TDM 業務の中心を 占めてきたのは抗てんかん薬で, 現在の測定対象 薬物はフェノバルビタール $(\mathrm{PB})$, フェニトイン

$\dagger$ 福岡市東区馬出3-1-1；3-1-1, Maidashi, Higashiku, Fukuoka-shi, 812-8582 Japan
(PHT), カルバマゼピン $(\mathrm{CBZ})$, バルプロ酸 (VPA)，およびゾニサミド（ZNS）である. 抗て んかん薬の測定件数は年間総測定件数の約 $50 \%$ に 相当するが, 近年徐々に減少傾向にあり, 早晚急 増中の免疫抑制薬に中心的位置を譲ると思われ る.

ところで, ZNS は他の抗てんかん薬と異なり 簡便な蛍光偏光免疫法 (Fluorescence polarization immunoassay, FPIA 法) の測定キット ${ }^{1)}$ が発売さ れておらず, 従って1996年に Enzyme linked im- 
munosorbent assay (ELISA 法) ${ }^{2)} に て$ 測定を開始し た.しかし ELISA 法は操作が煩雑な上, 高速液 体クロマトグラフィー法 (HPLC 法) ${ }^{3-4)}$ を用いた 測定值との比較検討において異常值を呈する症例 を経験したため，一部 HPLC 法と併用して測定 することとした。その一方で， HPLC 法は移動相 に有機溶媒を使用し，特に業務で用いる場合使用 総量がかなりの容量に及ぶため廃液処理や地球環 境への影響が慙念された。そこで新しい分離・分 析法として注目されているキャピラリ一電気泳動 法 $(\mathrm{CE} \text { 法 })^{5,6)}$ による ZNS および他の抗てんかん 薬の血中濃度同時測定法を開発した ${ }^{7,8)}$. 本論文 では，このCE 法を用いて中毒が疑われた患者の 原因薬剤としてフェニトインを迅速に同定した一 例を報告する。

\section{症例}

患者は 2 歳 5 力月の男児, 体重 $15 \mathrm{~kg}$, 身長 92 cm. 抗てんかん薬による薬物療法を施行中. 9 月13日午後, 小児科外来より抗てんかん薬の中毒 が疑われるとのことで VPA および ZNS 血中濃度 測定の緊急依頼があった. 現病歴としては, 当院 院外処方せんに基づき 9 月 5 日保険薬局で調剤さ れた薬品を服用した翌日より運動障害, 歩行障害 （フラフラ状態）が生じ, 当日午後 1 時すぎに当 院に緊急来院となった. 院外処方せんの処方内容 は以下のとおりである.

Rp.

$$
\begin{gathered}
\text { バルプロ酸シロップ（VPA：50mg/mL） } \\
360 \mathrm{mg} 2 \times \\
\text { ゾニサミド散（ZNS }: 200 \mathrm{mg} / \mathrm{g}) \\
10 \mathrm{mg} 2 \times \\
28 \text { 日分 }
\end{gathered}
$$

VPA の血中濃度は FPIA 法により迅速な測定が 可能であったが，当時ZNS の測定は ELISA 法を 中心に行っており, 加えて本来の ZNS の測定曜 日ではなかったため, 準備から測定までにかなり の時間を要すると予測された。そこでZNS の CE 法による血中濃度測定を試みた。

\section{方法}

VPAの血中濃度はFPIA 法により, ZNS の血 中濃度は CE 法により, 交付された製剤は篠田ら の方法 ${ }^{3)}$ に準じた HPLC 法により分析した. CE 法における測定条件を以下に示す。

\section{CE 装置9)}

CE 装置には diode array UV detector（DAD）を 備えた Hewlett-Packard 社製 $\mathrm{HP}^{3 \mathrm{D}} \mathrm{CE}$ システムを 用いた. キャピラリーカラムは同じく HewlettPackard 社のフューズドシリカ（溶融石英， $50 \mu \mathrm{m}$ ×有効長 $56 \mathrm{~cm}$ ）で，検出部位の内径を 3 倍に膨 張させることにより, 検出感度を上昇させたもの を使用した。

\section{2. 測定条件}

泳動液には50mM SDS+10mM Phosphate buffer (pH8.0)，泳動前のキャピラリー洗浄およびコン ディショニングとして泳動液を 5 分間泳動し, 注 入は $50 \mathrm{mmHg}$ の加圧下 2.0 秒間, 印加電圧は正の $30.0 \mathrm{kV}$, 温度は $30^{\circ} \mathrm{C}$, 検出波長は $210 \mathrm{~nm}$ を用い た.

3. 薬物添加標準血清および患者血清試料調製操 作

キャリブレーション用薬物添加標準血清は市販 ヒト血清またはボランティア血清に薬物標準溶液 を添加して作製した．薬物添加標準血清および患 者血清試料 $0.2 \mathrm{~mL}$ に, 内標準物質 n-propyl phydroxybenzoate $5 \mu \mathrm{g} / \mathrm{mL}$ を含む酢酸エチル $1 \mathrm{~mL}$ を加えて擋拌, 遠心した。 上清 $0.5 \mathrm{~mL}$ を窒素ガ ス下で蒸発乾固し， $5 \%$ エタノール溶液50 $\mu \mathrm{L}$ で 再溶解して CE 注入用試料とした。

\section{結果}

\section{CE 法の基礎的検討}

CE 法によるZNS および他の抗てんかん薬の分 離性, 定性能, 定量性に関する基礎的検討はすで に報告した ${ }^{7)}$. CBZ の代謝物を含む 6 種類の抗て んかん薬の分離は良好で, ZNS およびPHT はそ れぞれ4.2分，7.1分近傍に分離された(Fig.1A). 

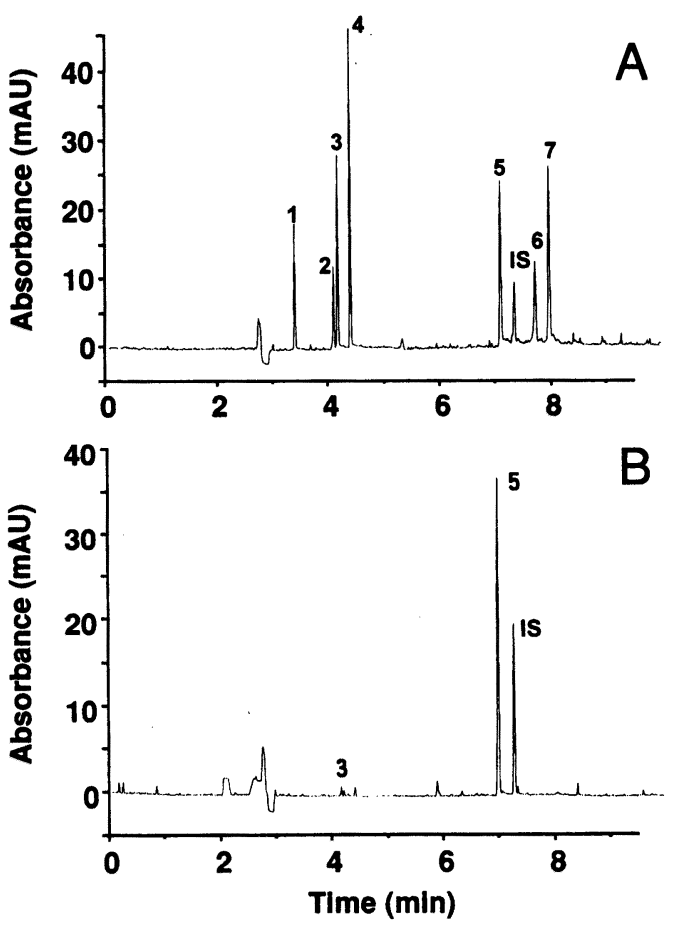

Fig. 1. Electropherograms Obtained from

(A) the extraction of serum spiked by standard mixtures of ethosuximide $(128 \mu \mathrm{g} / \mathrm{mL}: 1)$, primidone (16 $\mu \mathrm{g} / \mathrm{mL}: 2)$, zonisamide ( $32 \mu \mathrm{g} /$ $\mathrm{mL}: 3)$, phenobarbital $(48 \mu \mathrm{g} /$ $\mathrm{mL}: 4)$, phenytoin $(32 \mu \mathrm{g} / \mathrm{mL}$ : 5), n-propyl p-hydroxybenzoate (internal standard), carbamazepine -10, 11-epoxide $(10 \mu \mathrm{g} / \mathrm{mL}: 6)$ and carbamazepine $(12.8 \mu \mathrm{g} / \mathrm{mL}$ : 7); and

(B) the extraction of serum of the patient taking zonisamide $(10 \mathrm{mg} /$ day) and sodium valproate (360 $\mathrm{mg}$ /day). Migration time of each peak indicate that peak 3 and 5 correspond to zonisamide and phenytoin, respectively.

また薬物添加標準血清および患者血清における分 離ピークの DAD 吸収スペクトルを比較すること により各薬物の定性が可能であった。さらに， ZNS, PB，PHT およびCBZの定量性に関しては,
検量線の精度, 検出感度, 日内・日差誤差, HPLC 法・FPIA 法との比較検討により臨床上十 分な定量性が示された (Table 1$)^{1,3.4,7)}$.なお， VPA はUV 吸収を持たないためCE 法による測定 から除外した。

\section{2. 中毒を疑われた患者の血中濃度測定}

FPIA 法によるVPAの患者血中濃度測定值は $62.2 \mu \mathrm{g} / \mathrm{mL}, \mathrm{CE}$ 法による ZNS の測定值は $5.0 \mu \mathrm{g} /$ $\mathrm{mL}$ で，両薬凨とも中毒濃度以下であった。しか し, CE 法による分析から得られた分離ピーク に, 移動時間 (約 7 分) から PHT と推測される 極めて高いピークが検出された（Fig. 1 B).こ のピークから得られるUV吸収スペクトル (Fig. 2 B）をPHTの標準品が与える吸収スペク トル（Fig. 2A）と比較した結果, 同一であるこ とから本ピークはPHT と同定された。そこで迅 速性に優れた FPIA 法により再度患者血清中 PHT 濃度を測定したところ, $33.1 \mu \mathrm{g} / \mathrm{mL}$ と中毒域濃 度を示した。この結果は即時主治医に連絡され， 採血からの所要時間は約 2 時間であった。

\section{3. 交付された製剤の分析}

該当散㓮の一包の重量を測定したところ $0.473 \mathrm{~g}$ であった。 そのうち $100 \mathrm{mg}$ を秤量し，メタノー ル $10 \mathrm{~mL}$ に溶解した。メタノール溶液を蒸留水で 1000倍に希釈し HPLC 法で測定したところ，メ タノール溶液中 PHT 濃度は $8.71 \mu \mathrm{g} / \mathrm{mL}$ という結 果が得られた。すなわち散剤 $100 \mathrm{mg}$ 中に $87.1 \mathrm{mg}$ のPHTを含有するという概算が得られた。 これ を一包 $0.5 \mathrm{~g}$ あたりに換算すると $0.4355 \mathrm{~g}$ に相当 し，調剤時の乳糖賦形量にほぼ相当した。なお， ZNS のピークもわずかに検出されたが, 散剤中 の ZNS 量に相当するものと推察された.

\section{4. 患者の経過と対処}

本症例におけるその後の抗てんかん薬の血中濃 度推移をTable 2 に示す. 患者は 9 月13日に PHTの中毒が判明した時点で抗てんかん薬の服 薬をすべて中止した。9月15日の血中濃度測定で PHT は21. $5 \mu \mathrm{g} / \mathrm{mL}$ と治療域の上限付近の高值を 示したが, VPA は34.7 $\mu \mathrm{g} / \mathrm{mL}$ と治療域以下に下 
Table 1. Analysis Data of Antiepileptic Drugs by CE, HPLC and FPIA Methods

\begin{tabular}{|c|c|c|c|c|}
\hline $\begin{array}{l}\text { Anti- } \\
\text { epileptic } \\
\text { drug }\end{array}$ & $\begin{array}{c}\text { Calibration curve } \\
\text { with } \mathrm{CE}^{\mathrm{a})} \\
\text { (range }, \mu \mathrm{g} / \mathrm{mL} \text { ) }\end{array}$ & $\begin{array}{l}\text { Detection limit } \\
\qquad(\mu \mathrm{g} / \mathrm{mL})\end{array}$ & $\begin{array}{c}\text { Inter-day precisionb) } \\
\text { C.V.(\%) }\end{array}$ & $\begin{array}{c}\text { CE vs. } \\
\text { HPLC or FPIAc) }\end{array}$ \\
\hline ZNS & $r=0.991(5-40)$ & $\begin{array}{l}3.0 \text { (CE) } \\
0.1-0.5 \text { (HPLC) }\end{array}$ & $\begin{array}{ll}\text { 8.4- 9.3 } & \text { (CE) } \\
5.1-9.1 & \text { (HPLC) }\end{array}$ & $\mathrm{r}=0.981(\mathrm{HPLC})$ \\
\hline PB & $r=1.000(7.5-60)$ & $\begin{array}{ll}2.5 & \text { (CE) } \\
1.1 & \text { (FPIA) }\end{array}$ & $\begin{array}{ll}9.9-11.1 & \text { (CE) } \\
2.4-2.8 & \text { (FPIA) }\end{array}$ & $r=0.992$ (FPIA) \\
\hline PHT & $r=0.996(5-40)$ & $\begin{array}{ll}0.8 & \text { (CE) } \\
0.5 & \text { (FPIA) }\end{array}$ & $\begin{array}{ll}3.2-7.3 & \text { (CE) } \\
2.7-3.6 & \text { (FPIA) }\end{array}$ & $\mathrm{r}=0.998$ (FPIA) \\
\hline CBZ & $r=0.997(2-16)$ & $\begin{array}{ll}0.6 & \text { (CE) } \\
0.5 & \text { (FPIA) }\end{array}$ & $\begin{array}{ll}5.8-9.5 & \text { (CE) } \\
2.0-2.7 & \text { (FPIA) }\end{array}$ & $\mathrm{r}=0.986$ (FPIA) \\
\hline
\end{tabular}

a) Internal standard method

b) Reproducibility of relative peak area

c) Linear regression analysis of antiepileptic drug levels determined by CE and HPLC or FPIA methods

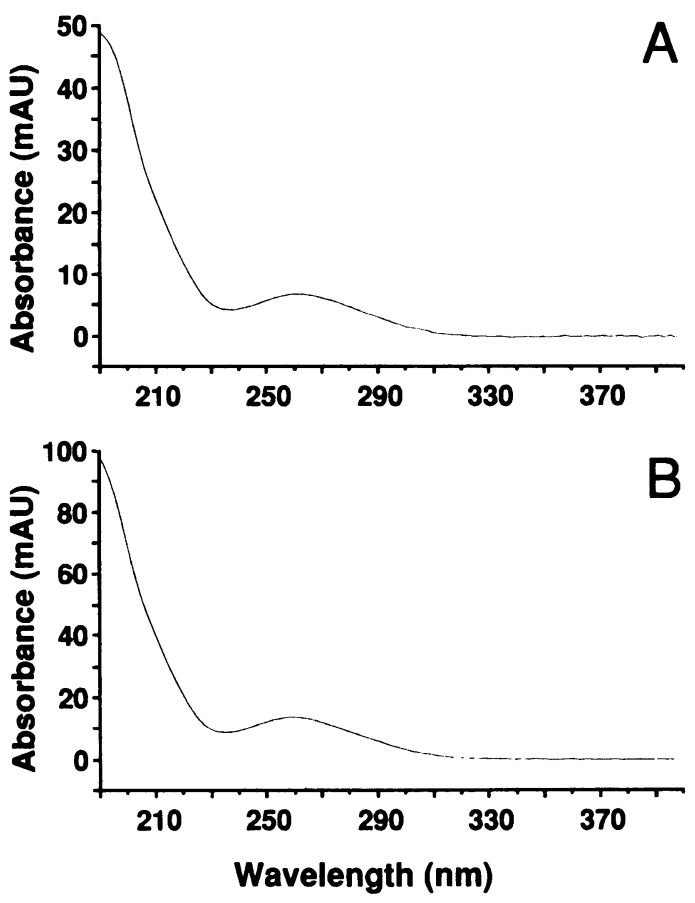

Fig. 2. Absorption Spectrum of A and B Obtained as Slices from Data in Fig. $1 \mathrm{~A}$ and $1 \mathrm{~B}$, respectively, Showing Phenytoin
がっていたので, VPAによる抗てんかん薬療法 を再開した９月19日にはPHTの血中濃度は FIPA 法の測定感度以下まで減少し，一方 VPA は 治療域まで上昇した。

\section{考察}

$\mathrm{CE}$ 法は電場中の溶質の電荷や分子量の違いに よる移動度の差を利用した分離・分析法である。 従来のスラブゲルあるいはディスク電気泳動と異 なり，25-150 $\mu \mathrm{m}$ の微細な孔径のキャピラリー を用いることにより， ジュール熱の発生が抑えら れるとともに熱が効率よく放散されるので高電圧 の印加が可能となる。その結果分析時間が短縮さ れ, 高い分離効率と分解能が得られる。 また平面 的な電気浸透流（EOF：負に帯電したフューズド シリカ表面 Si-O-に水和陽イオンが引き寄せら れ，電圧を印加することによって生じる陰極への 流れ）が発生するため理論段数が非常に高い.

その他，(1)試料の必要量が数 $\mu \mathrm{L}$ と微量であ る，(2)試料を前処理なしに直接分析できる，(3) 測定系の開発が容易で，操作も簡便である，(5) 有機溶媒を必要とせず，環境污染が少ない，(6) 
Table 2. Antiepileptic Drug Concentrations in the Patient Serum

\begin{tabular}{|c|c|c|c|c|}
\hline Antiepileptic drug & Day & $9 / 13$ & $9 / 15$ & $9 / 19$ \\
\hline & & $(\mu \mathrm{g} / \mathrm{mL})$ & $(\mu \mathrm{g} / \mathrm{mL})$ & $(\mu \mathrm{g} / \mathrm{mL})$ \\
\hline PHTa) & & 33.1 & 21.5 & $<0.5$ \\
\hline VPA $\left.{ }^{b}\right)$ & & 62.2 & 34.7 & 58.9 \\
\hline ZNSc) & & 3.01 & $<3.0$ & $<3.0$ \\
\hline
\end{tabular}

a) FPIA method (detection limit: $0.5 \mu \mathrm{g} / \mathrm{mL}$ ), b) FPIA method,

c) Capillary electrophoresis method (detection limit: $3.0 \mu \mathrm{g} / \mathrm{mL}$ )

泳動コストが極端に低い，などの特徴を有す る5,6).ZZN は FPIA 法による測定キットが発売さ れていないため, ELISA 法およびHPLC 法によ り測定されている. 初めて開発された CEによる ZNS 測定法は，煩雑な ELISA 法に替わりうる方 法である。またZNS の測定法として最も一般的 である HPLC 法と比較した場合，簡便性，定量 性で優れているとはいえないが（Table 1)，環 境指向性, 測定コストパフォーマンスの高さでは より優れている．従って，ZNSの血中濃度が有 効濃度域（10-30 $\mu \mathrm{g} / \mathrm{mL})$ より極端に低い場合 を除けば，ELISA 法，HPLC 法と同等あるいはそ れ以上の有用性を持つと思われる。特に抗てんか ん薬中毒時やサリチル酸治療時のように血中濃度 が十分高く，さらに他の薬物も中毒原因として考 えられる場合はその利点が一層発揮される ${ }^{10)}$. なお，CE 法によるZNS 定量法の測定感度が十分 でない点に関しては, 前処理法の改善, 高感度七 ル11の使用などの検討を行っているところであ る.

本症例は本来乳糖で行うべき ZNS の賦形が， 何らかの原因でPHTにより行われたことが推察 された. FPIA 法および ELISA 法は目的とする薬 物以外の定量は不可能である．処方薬以外の抗て んかん薬を誤って摄取されていた本症例では, 通
常ルーチンで行っている FPIA 法およびELISA 法 による定量のみではPHT 中毒を発見できず， HPLC 法や CE 法などクロマトグラフィーを原理 とする分析が欠かせないことがわかった．特に CEは通常 DAD装置を標準装備しており， Fig. 2 に示すように，患者血清から得られる目的 ピークの吸収スペクトルとすでに分離・登録済み の標準品スペクトルを比較できるので，定性能に 優れている．著者らは臨床での中毒症例の多い7 種類の抗てんかん薬や 8 種類の非ステロイド性抗 炎症薬等について，泳動条件下での UV 吸収スぺ クトルを登録し，さらに他の医薬品も追加中であ る.

本症例では, 採血後, 血清分離 (10分), 前処 理（25分）および泳動（15分）を含めて約 1 時間 で分離が終了した．さらに原因薬物が抗てんかん 薬であったことが迅速な定性，対応に結びついた が，他の薬物による中毒例でも，CE 法による分 析が有用であることが示唆された．CE 法はさら に環境性やランニングコストの面でも有望な測定 法である．従って，現在抗てんかん薬に加え，医 療用や家庭用医薬品として汎用され，中毒の原因 となりやすい薬物類の CE によるスクリーニング 法の検討を進めている ${ }^{10)}$. 


\section{引用文献}

1) TDx assay manual, Dinabot Laboratories.

2) K. Kaibe, S.Nishimura, H. Ishii, N.Sunahara, S. Naruto and S. Kurooka, Clin.Chem., 36, 24-27 (1990).

3) 篠田正彦, 秋田昌宏, 長谷川雅哉, 長谷川高明, 鍋島俊隆, 病院薬学, 21, 185-190 (1995).

4) K. Furuno, R.Oishi, Y.Gomita and K. Eto, $J$. Chromatogr. B, 656, 456-9 (1994).

5）本田進, 寺部茂編, “キャピラリー電気泳動 基 礎と実際”, 講談社, 1995.

6) D.N.Heiger, “キャピラリー電気泳動入門”,
Hewlett Packard, Waldbronn, 1994.

7) K.Makino, Y.Goto, M.Sueyasu, K.Futagami, Y. Kataoka and R. Oishi, J. Chromatogr. B, 695, 417-25 (1997).

8) Y. Kataoka, K. Makino and R. Oishi, Electrophoresis, 19, 2856-60 (1998) .

9) D.N. Heiger, P. Kaltenbach and H.J.P. Sievert, Electrophoresis, 15, 1234-47 (1994).

10) Y. Goto, K. Makino, Y. Kataoka, H. Shuto and R. Oishi, J. Chromatogr. B, 706, 329-35 (1998).

11) Y. Mrestani and R. Neubert, Electrophoresis, 19, 3022-5 (1998). 